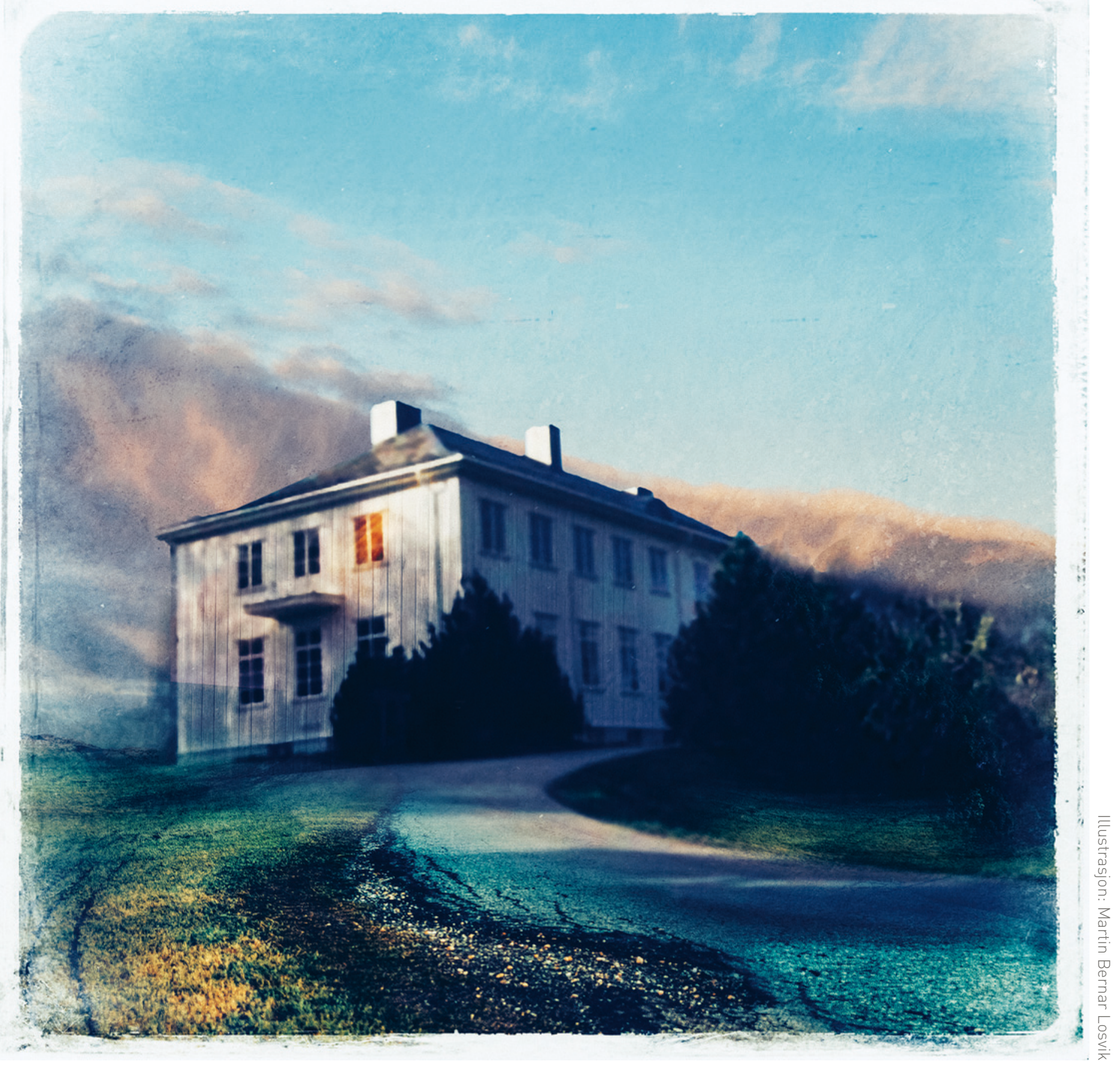

\title{
Høvdinggården Legekontor
} Kontoret er lokalisert i en ærverdig trebygning fra 1927. Byen er Steinkjer, som ligger innerst i Trond-
heimsfjorden og er den største i Nord-Trøndelag med over 20000 innbyggere. På legekontoret jobber
det sju leger, en sykepleier og fem helsesekretærer. 